\title{
Badania przejazdu pojazdów szynowych przez tory wichrowate $w$ warunkach quasi-statycznych $z$ uwzględnieniem kąta nabiegania koła na szynę
}

\begin{abstract}
$W$ artykule przedstawiono nowatorskie podejście do problemów bezpieczeństwa przejazdu pojazdów przez tory wichrowate $w$ warunkach quasi-statycznych $z$ uwzględnieniem kata nabiegania koła na szynę. W ten sposób kryterium Nadala zostało rozszerzone o nastęny parametr. Można wyciagnać wniosek, że kryterium to ulega zmianie, wskutek postęu prac analityczno-badawczych.
\end{abstract}

\section{WSTĘP}

Bezpieczeństwo przejazdu pojazdu przez tory wichrowate $\mathrm{w}$ warunkach quasi-statycznych jest jednym z najistotniejszych problemów kolejnictwa. Kryterium bezpieczeństwa przed wykolejeniem zostało wprowadzone przez Nadala w 1908 roku. Rozwój tego kryterium oraz zabezpieczenie pojazdów szynowych przed wykolejeniem, jest procesem ciaggłym i podlega dalszym badaniom $[2,6,7,8]$, pomimo istotnych osiągnięć $\mathrm{w}$ tej dziedzinie dla wagonów towarowych, co jest wyrażone raporcie ORE/ERRI B55 Rp.8 [13]. W świetle dzisiejszej wiedzy istotnymi czynnikami, które działają w kierunku polepszenia bezpieczeństwa przed wykolejeniem w warunkach quasi-statycznych są:

$>$ wielkość poprzecznych sił prowadzących $\mathrm{Y}$, działających $\mathrm{w}$ punkcie styku koła i szyny $\mathrm{w}$ kierunku poprzecznym,

$>$ wielkość nacisków pionowych Q koła (niem. „Radaufstandskräfte”), działających w punkcie styku koła i szyny oraz ich rzeczywisty rozkład w pojeździe,

$>$ wartość współczynnika tarcia $\mu$ między kołem a szyną,

$>$ zarys koła, a zwłaszcza kąt pochylenia obrzeża $\gamma$, przyjęty w stanie nowym na poziomie 70 ? zgodnie $\mathrm{z}$ normą europejską PN-EN 13715+A1:2011 wg [11],

$>$ wichrowatość toru, mierzona $\mathrm{w}$ promilach $\mathrm{i}$ określona $\mathrm{w}$ przepisach utrzymania infrastruktury,

$>$ wielkość kątów nabiegania $\alpha$ koła pojazdu na szynę,

$>$ promień łuku toru $\mathrm{R}$, przez który przejeżdża pojazd oraz wielkość pochylenia rampy przechyłkowej toku zewnętrznego szyny na łuku o promieniu $\mathrm{R}$,

$>$ bazy wózka $2 \mathrm{a}$, w przypadku pojazdów czteroosiowych oraz baza pojazdu w przypadku wagonów dwuosiowych,

$>$ sztywność skrętna nadwozia,

$>$ sztywność usprężynowania,

$>$ sztywność skrętna ramy wózka.

\section{Wskaźnik wykolejenia}

Wskaźnik wykolejenia, który jest znany od 1908 roku jako kryterium Nadala, przedstawia się następująco:

$$
\left(\frac{\mathrm{Y}}{\mathrm{Q}}\right)_{\gamma=70^{\circ}, \mu=0,36} \leq 1,2
$$

gdzie:

Y- siła prowadząca, działająca $\mathrm{w}$ punkcie styku $\mathrm{w}$ kierunku poprzecznym (niem. „laterale Führungskra$\mathrm{ft}$ ")

Q- siła nacisku pionowego koła na szynę (niem. „Radaufstandskraft").

Kryterium w takiej formie, aby można było je bardziej zrozumieć, musi ulec rozwinięciu do następującej formy:

$$
\frac{\mathrm{Y}}{\mathrm{Q}}=\frac{\operatorname{tg} \gamma-\mu}{1+\mu \cdot \operatorname{tg} \gamma} \leq 1,2
$$

gdzie:

$\gamma$-kąt pochylenia obrzeża (niem. „Spukranzwinkel”),

$\mu$ - współczynnik tarcia pomiędzy kołem, a szyną (niem. „Reibwert”)

Rozkład sił oraz kąt pochylenia obrzeża jest przedstawiono na rys. 1

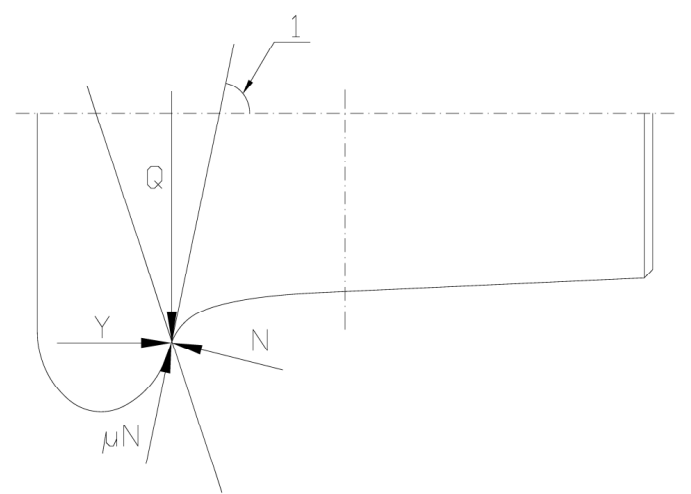

Rys.1. Siły działające w punkcie styku koło-szyna podczas przejazdu przez tuk toru 
Legenda:

Y- siła poprzeczna działająca w punkcie styku koło-szyna

Q- siła pionowa działająca w punkcie styku koło-szyna

$\mathrm{N}$-siła normalna, prostopadła do linii, wyznaczającej kąt pochylenia obrzeża

$\mu \mathrm{N}$ - siła tarcia, działająca w punkcie styku koło-szyna.

Proces wykolejenia odbywa się w wyniku wspinania koła (niem. „das Aufklettern des Rades”) w rejonie obrzeża po główce szyny. Wspinanie koła bokiem obrzeża po zarysie zewnętrznym szyny odbywa się w wyniku działania siły tarcia $\mathrm{T}=\mu \cdot \mathrm{N}$ (niem. „Tangentialkraft”) oraz składowej siły poprzecznej Y. Wartość tej siły jest tym większa im większy jest współczynnik tarcia pomiędzy kołem, a szyną. Jeżeli stosunek sił Y i Q przekroczy wartość wynosząca 1,2, to wówczas, prawdopodobne jest wykolejenie. Należy jednak podkreślić, że kryterium to obowiązuje dla kąta pochylenia obrzeża $\gamma=70^{\circ}$ oraz współczynnika tarcia na styku koło-szyna wynoszącego $\mu=0,36$.

Po wstawieniu danych $\gamma=70^{\circ}$ oraz $\mu=0,36$ do wzoru (2) otrzymuje się:

$$
\frac{Y}{Q}=\frac{\operatorname{tg} 70-0,36}{1+0,36 \cdot \operatorname{tg} 70}=\frac{2,7474-0,36}{1+0,36 \cdot 2,7474}=1,200
$$

Tak więc poprawnie sformułowane kryterium Nadala przedstawia się następująco:

$$
\left(\frac{\mathrm{Y}}{\mathrm{Q}}\right)_{\gamma=70^{0}, \mu=0,36} \leq 1,2
$$

Wskaźnik wykolejenia zależy w dużym stopniu od kąta pochylenia obrzeża $\gamma$. Zależność tę przedstawiono w tabeli 1.

\section{Zależność wskaźnika wykolejania (Y/Q) od kąta pochylenia} obrzeża koła Tabela 1

\begin{tabular}{|c|c|c|}
\hline I.p. & $\begin{array}{c}\text { Wartość kąta } \\
\text { pochylenia } \\
\text { obrzeża } \gamma\end{array}$ & $\begin{array}{c}\text { Wartość } \\
\text { wskaźnika } \\
\text { wykolejenia (Y/Q) }\end{array}$ \\
\hline $\mathbf{1}$ & $60^{\circ}$ & 0,845 \\
\hline $\mathbf{2}$ & $61^{\circ}$ & 0,875 \\
\hline $\mathbf{3}$ & $62^{\circ}$ & 0,906 \\
\hline $\mathbf{4}$ & $63^{\circ}$ & 0,939 \\
\hline $\mathbf{5}$ & $64^{\circ}$ & 0,972 \\
\hline $\mathbf{6}$ & $65^{\circ}$ & 1,007 \\
\hline $\mathbf{7}$ & $66^{\circ}$ & 1,042 \\
\hline $\mathbf{8}$ & $67^{\circ}$ & 1,079 \\
\hline $\mathbf{9}$ & $68^{\circ}$ & 1.118 \\
\hline $\mathbf{1 0}$ & $69^{\circ}$ & 1,158 \\
\hline $\mathbf{1 1}$ & $70^{\circ}$ & 1,200 \\
\hline $\mathbf{1 2}$ & $71^{\circ}$ & 1,243 \\
\hline $\mathbf{1 3}$ & $72^{\circ}$ & 1,289 \\
\hline $\mathbf{1 4}$ & $73^{\circ}$ & 1,336 \\
\hline $\mathbf{1 5}$ & $74^{\circ}$ & 1,386 \\
\hline $\mathbf{1 6}$ & $75^{\circ}$ & 1,438 \\
\hline $\mathbf{1 7}$ & $76^{\circ}$ & 1,493 \\
\hline $\mathbf{1 8}$ & $77^{\circ}$ & 1,551 \\
\hline $\mathbf{1 9}$ & $78^{\circ}$ & 1,612 \\
\hline $\mathbf{2 0}$ & $79^{\circ}$ & 1,677 \\
\hline $\mathbf{2 1}$ & $80^{\circ}$ & 1,746 \\
\hline & & \\
\hline
\end{tabular}

Należy jednak zaznaczyć, że kąt pochylenia obrzeża $\gamma$ można używać do oceny bezpieczeństwa przed wykolejeniem jeśli główka szyny nie jest na tyle zużyta, że ma wpływ na ostateczny kąt pochylenia. Jeśli główka szyny jest na tyle zużyta, jak pokazano na rys.4, to wówczas rzeczywisty kąt styku wynosi $\alpha=55^{\circ}$ podczas przejazdu pojazdu $\mathrm{z}$ kołami o kącie pochylenia obrzeża $\gamma=70^{\circ}$.

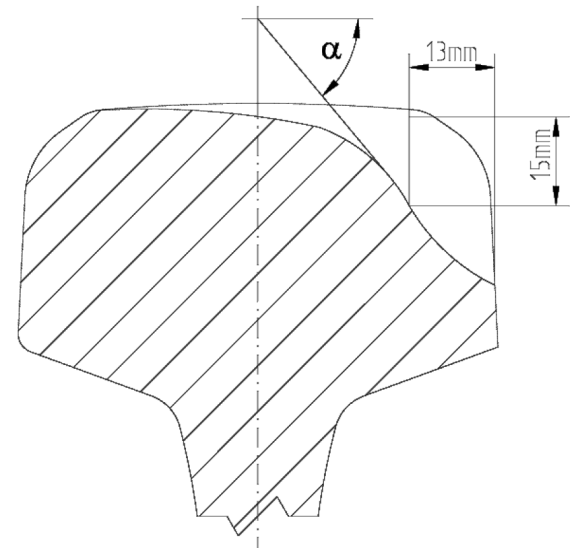

Rys.2. Maksymalne dopuszczalne zużycie szyny, które wywołuje kąt pochylenia obrzeża $\alpha=55^{\circ}$

Przyjmując kąt pochylenia obrzeża $\alpha=55^{\circ}$ oraz współczynnik tarcia $\mu=0,36$ i wstawiając do wzoru (2) otrzymuje się:

$$
\frac{\mathrm{Y}}{\mathrm{Q}}=\frac{\operatorname{tg} 55^{0}-0,36}{1+0,36 \cdot \operatorname{tg} 55^{0}} \leq 0,705
$$

\section{Wskaźnik wykolejenia, a kąt nabiegania}

W przypadku przejazdu pojazdu przez tuk dochodzi bardzo często do nabiegania koła pojazdu na szynę pod kątem $\alpha$, który nazywa się w kolejnictwie kątem nabiegania (niem. „Anlaufwinkel”, ang. „stricking angle”, fr „,angle d' attage”). Sytuację koła pojazdu na tuku toru opisuje rys.2 oraz rys.3.

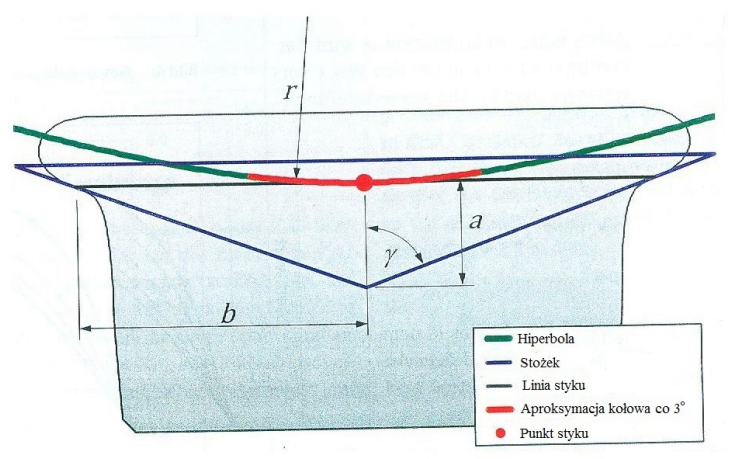

Legenda:

a- mała półoś elipsy

b- duża półoś elipsy

r- promień krzywizny wierzchołka hiperboli

$\gamma$ - kąt pochylenia obrzeża

Rys.3. Aproksymacja przebiegu punktu styku przez łuk toru wg [2] 


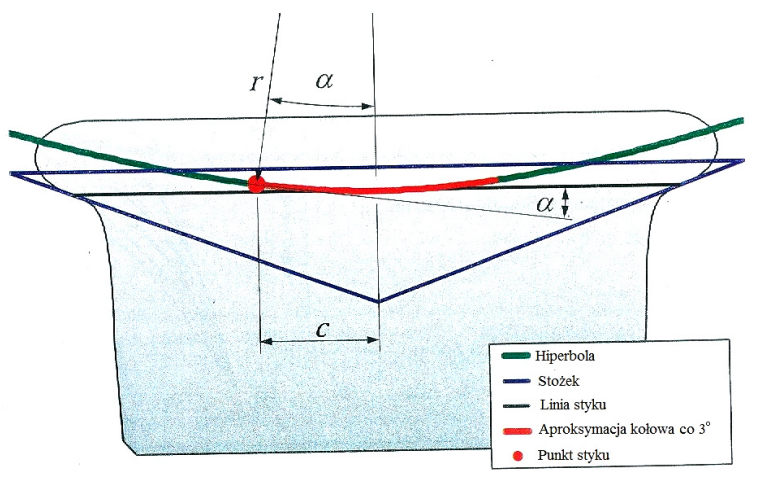

Rys.4. Przemieszczenie punktu styku podczas przejazdu koła pojazdu przez łuk toru wg [2]

Kąty nabiegania $\alpha$ mogą przyjmować różne wartości, przy czym jedną z maksymalnych wartości $\alpha=3,23^{\circ}$ wyliczono podczas przejazdu wagonu towarowego 218K (Hbbins) przez tuk o promieniu $\mathrm{R}=70 \mathrm{~m}[2,3]$. Jak wynika $\mathrm{z}$ doświadczeń eksploatacyjnych pojazdów tramwajowych duże kąty nabiegania ok. $3^{\circ}$, występują podczas przejazdu przez tuk o promieniu $\mathrm{R}=17,5 \mathrm{~m} \mathrm{i}$ wózków o bazie $1850 \mathrm{~mm}$ [2]. Duże kąty nabiegania $\alpha$ powyżej 3? występują podczas przejazdu wagonów towarowych przez łuki o małym promieniu, tzw. tory warsztatowe, co zostało wykazane w $[6 \div 8]$.

Analizując rys. 3 oraz rys. 4 można zauważyć, że jeśli punkt styku koło szyna wędruje na wycinku hiperboli, to wówczas powstaje kąt nabiegania $\alpha$.

Punkt wierzchołkowy (niem. „Scheitelpunkt”) hiperboli można wyznaczyć ze wzoru:

$$
r=\frac{b^{2}}{a}
$$

Półoś $\mathrm{b}$ odpowiada promieniowi koła $\mathrm{R} \mathrm{w}$ punkcie styku.

Półoś a może być wyliczona za pomocą kąta pochylenia obrzeża na podstawie następującego wzoru:

$$
\mathrm{a}=\frac{\mathrm{R}}{\tan \gamma}
$$

Z zależności (6) oraz (7) wynika zależność dla aproksymowanego przemieszczenia promienia koła:

$$
\mathrm{r}=\mathrm{R} \cdot \tan \gamma
$$

W wyniku kąta nabiegania $\alpha$ punkt styku na kole przemieszcza się na odcinku drogi c, w wyniku czego można zapisać:

$$
\mathrm{c}=\mathrm{r} \cdot \sin \alpha
$$

względnie:

$$
\mathrm{c}=\mathrm{R} \cdot \tan \gamma \cdot \sin \alpha
$$

Skośne nabieganie koła pojazdu na szynę przedstawia również rys. 5 .

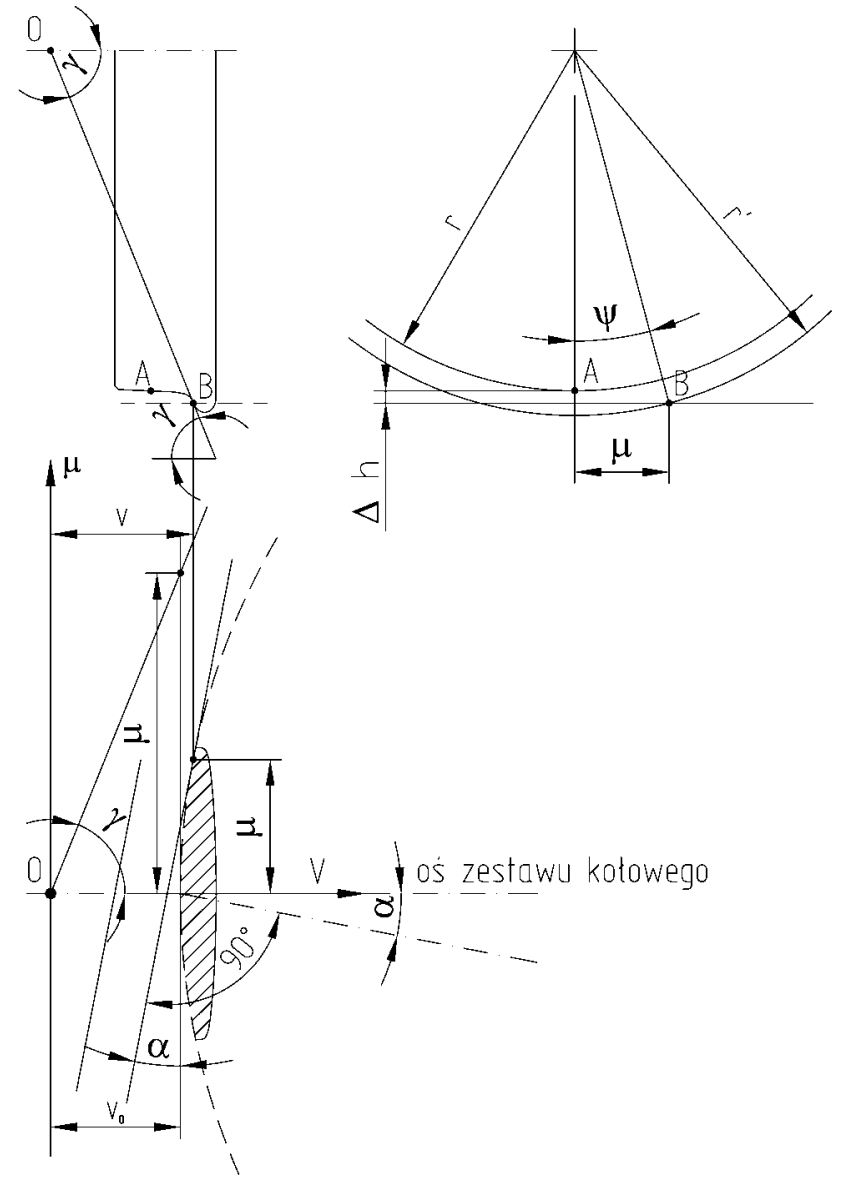

Rys.5. Skośne nabieganie koła na szynę

\section{Oznaczenia na rys.5:}

$$
\begin{aligned}
& \text { A, B punkty styku koła z szyną, odpowiednio na powierzchni } \\
& \text { tocznej i obrzeżu koła } \\
& \gamma \text { - kąt pochylenia obrzeża } \\
& \alpha \text { - kąt nabiegania koła na szynę } \\
& \mu \text { - współczynnik tarcia } \\
& \text { r- promień powierzchni tocznej } \\
& \text { r- promień obrzeża, sięgający do ostatniego punktu na boku } \\
& \text { obrzeża } \\
& \Delta \text { h- odległość w kierunku pionowym pomiędzy punktami A i B. }
\end{aligned}
$$

\subsection{Uwzględnienie poślizgu podczas jazdy przez luk toru}

Poślizg w kierunku pionowym można określić z rys.6.

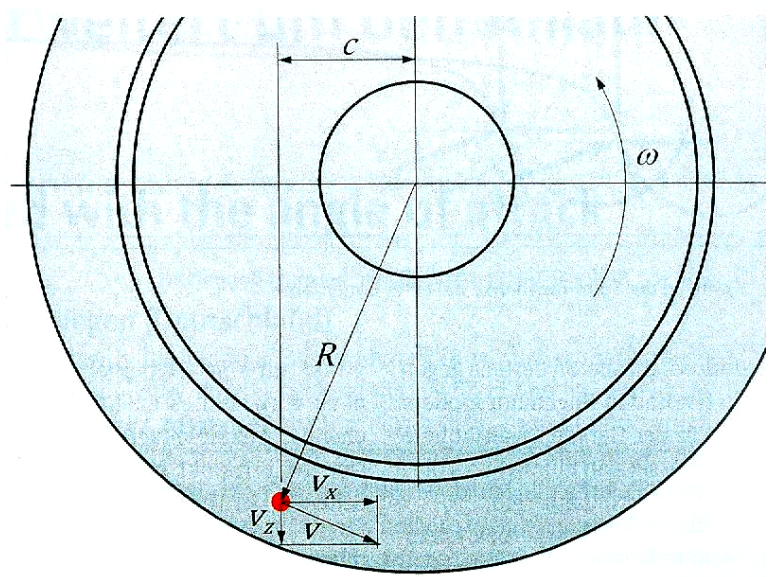

Rys.6. Prędkości przy przemieszczeniu punktu styku wg [2] 
Legenda:

R-promień punktu styku koła i szyny

c- przemieszczenie punktu styku koła i szyny (punkt styku B znajduje się na obrzeżu koła)

$\omega$ - prędkość obrotowa koła

v- prędkość liniowa w punkcie styku

$\mathrm{v}_{\mathrm{x}}$ - składowa prędkości w kierunku jazdy

$\mathrm{v}_{\mathrm{y}}$ - składowa prędkości $\mathrm{w}$ kierunku poprzecznym do kierunku jazdy.

Przemieszczeniu c punktu styku, wynikającemu z prędkości na kole towarzyszy poślizg. Poślizg w kierunku pionowym można wyznaczyć z następującej zależności:

$$
s_{\mathrm{Z}}=\frac{\mathrm{V}_{\mathrm{z}}}{\mathrm{V}}
$$

Z warunków geometrycznych wynika zależność:

$$
\frac{\mathrm{V}_{\mathrm{Z}}}{\mathrm{V}}=\frac{\mathrm{c}}{\mathrm{R}}
$$

Z zależności (11) wynika wzór na poślizg w kierunku pionowym:

$$
\mathrm{S}_{\mathrm{z}}=\tan \gamma \cdot \sin \alpha
$$

W karcie UIC 510-2 [10] znajduje się zależność, określająca zależność współczynnika tarcia od poślizgu:

$$
\left(\frac{1}{\mu}\right)^{\mathrm{n}}=\left(\left(\frac{1}{\mu_{\mathrm{s}}}\right)^{\mathrm{n}}+\left(\frac{1}{\mathrm{~K} \cdot \mathrm{s}_{\mathrm{y}}}\right)^{\mathrm{n}}\right)
$$

Poszczególne parametry wyrażają się wzorami:

$$
\begin{gathered}
\mu_{\mathrm{S}}=\frac{1}{1000} \cdot\left(\mathrm{Q}^{2}-24,25 \mathrm{Q}+571,5\right) \\
\mathrm{K}=\mathrm{Q}^{2}-24,25 \cdot \mathrm{Q}+219,5 \\
n=0,05 \cdot Q+2,2
\end{gathered}
$$

gdzie: tonach.

-Q nacisk pionowy koła na szynę wyrażony w

$$
\mu=\left(\left(\frac{1}{\mu_{\mathrm{s}}}\right)^{\mathrm{n}}+\left(\frac{1}{\mathrm{~K} \cdot \mathrm{s}_{\mathrm{y}}}\right)^{\mathrm{n}}\right)^{-\frac{1}{\mathrm{n}}}
$$

Równanie (17) można aproksymować do funkcji wykładniczej:

$$
\mu=\mu_{\mathrm{s}} \cdot\left(1-\mathrm{e}^{-\mathrm{d} \cdot \mathrm{s}_{\mathrm{y}}}\right)
$$

Wyraz d wyznacza się ze wzoru empirycznego:

gdzie:

$$
\mathrm{d}=-10 \cdot \mathrm{Q}+460
$$

Q- nacisk koła w tonach.

$\mathrm{Na}$ rys.7 przedstawiono graficzne zależności pomiędzy współczynnikiem tarcia i poślizgiem, natomiast na rys. 8 przedstawiono tzw. krzywe aproksymacyjne.

Zakładając, że przebieg współczynnika tarcia w zależności od poślizgu jest niezależny od kierunku, względnie zależność współczynnika tarcia od poślizgu pionowego przebiega identycznie jak zależność współczynnika tarcia od poślizgu poprzecznego. Obowiązuje więc równanie:

$$
s_{y}=s_{Z}
$$

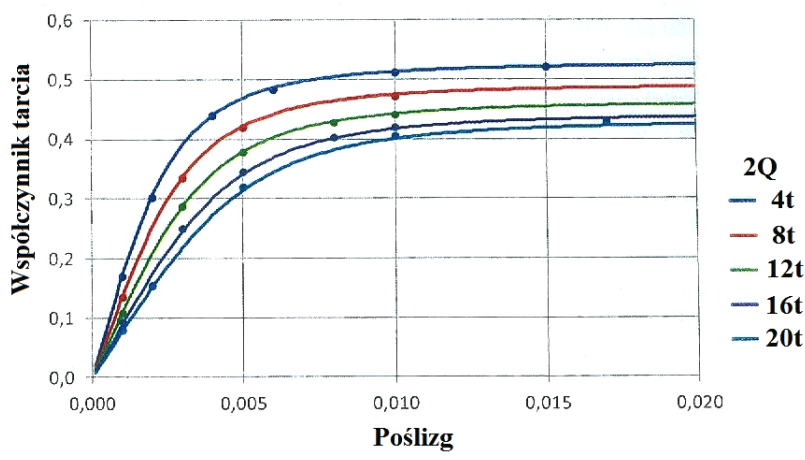

Rys.7. Związek między współczynnikami tarcia koła-szyny i poślizg dla różnych nacisków pionowych zestawu kołowego $2 \mathrm{Q}$ na tor wg [2]

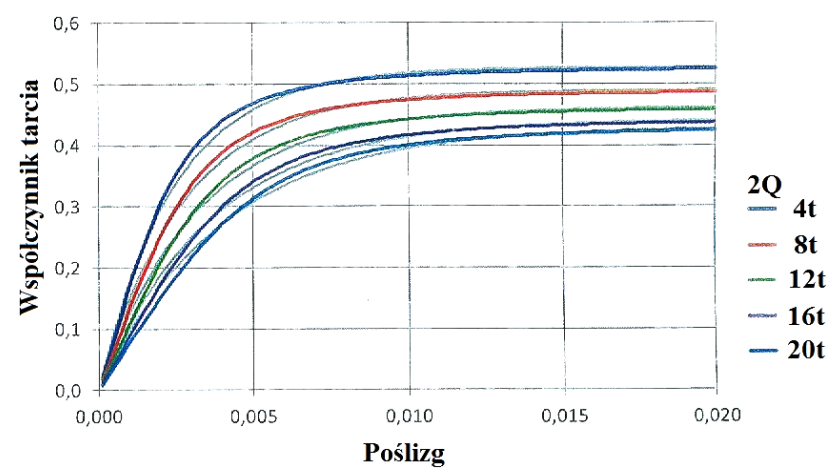

Rys.8. Aproksymacja ustalonych krzywych w karcie UIC 510-2 [10] poprzez funkcję wykładniczą dla różnych pionowych nacisków zestawów kołowych (2Q) na tor wg [2]

Niniejszą funkcję można wyrazić za pomocą aproksymacji przez funkcję wykładniczą:

$$
\frac{\mathrm{Y}}{\mathrm{Q}}=\frac{\tan (\gamma)-\mu_{\mathrm{S} \cdot}\left(1-\mathrm{e}^{-\mathrm{d} \cdot \tan \gamma \cdot \sin \alpha}\right)}{1+\mu_{\mathrm{S}}\left(1-\mathrm{e}^{-\mathrm{dtan} \gamma \cdot \sin \alpha}\right) \cdot \tan (\gamma)}
$$

Kąt nabiegania $\alpha$ koła pojazdu na szynę wyraża się wzorem:

gdzie:

$$
\alpha=\frac{2 \mathrm{a}}{2} \cdot \frac{1}{\mathrm{R}}
$$

2a-baza pojazdu

$\mathrm{R}$ - promień łuku toru.

$\mathrm{Na}$ rys.9 przedstawiono zależność współczynnika (Y/Q) wg kryterium Nadala (czerwona linia) oraz rozszerzoną wartość współczynnika Nadala o kąt nabiegania dla kąta pochylenia obrzeża $70^{\circ}$, nacisku zestawu kołowego na tor wynoszącego $19 \mathrm{t}$ oraz współczynnika tarcia $\mu=0,36$ i dla różnych promieni łuku toru.

Jak widać z rys.9 przy uwzględnieniu kąta nabiegania kryterium Nadala przyjmuje większe wartości od ustalonej w przepisach 1,2 . Jeśli tak, to należy uznać, że w kryterium Nadala istnieją rezerwy, zależne od kąta nabiegania koła pojazdu na szynę. Krzywa wg Nadala, uwzględniająca kąt nabiegania dla większych jego wartości jest tożsama $\mathrm{z}$ tradycyjnym kątem nabiegania. Na rys.10 przedstawiono zależności wskaźnika wykolejenia od kąta nabiegania i łuku toru, dla kątów 
pochylenia obrzeża, wynoszących odpowiednio: $\gamma=80^{\circ}, \gamma=76^{\circ}, \gamma=73^{\circ}, \gamma=70^{\circ}, \gamma=68^{\circ}, \gamma=64^{\circ}, \gamma=60^{\circ}$ i $\gamma=50^{\circ}$. Wykresy wskaźnika wykolejania (Y/Q) przedstawiono dla nacisku zestawu kołowego na tor wynoszącego 19 t, współczynnika tarcia $\mu=0,36$ i pojazdu o bazie $2 \mathrm{a}=2,5 \mathrm{~m}$.

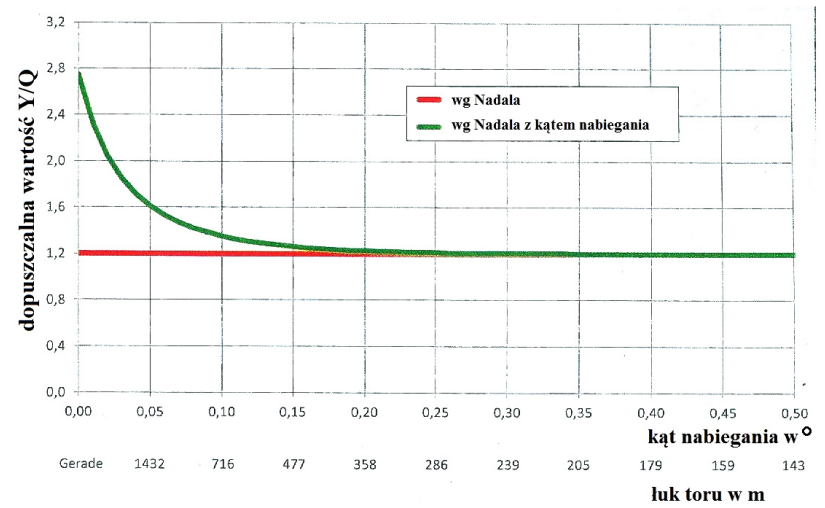

Rys.9. Dopuszczalne wartości (Y/Q) wg kryterium Nadala i wg rozszerzonego równania wg Nadala w zależności od kąta nabiegania dla kąta pochylenia obrzeża $70^{\circ}, 2 \mathrm{Q}=19 \mathrm{t}$ i współczynnika tarcia $\mu=0,36$ wg [2]

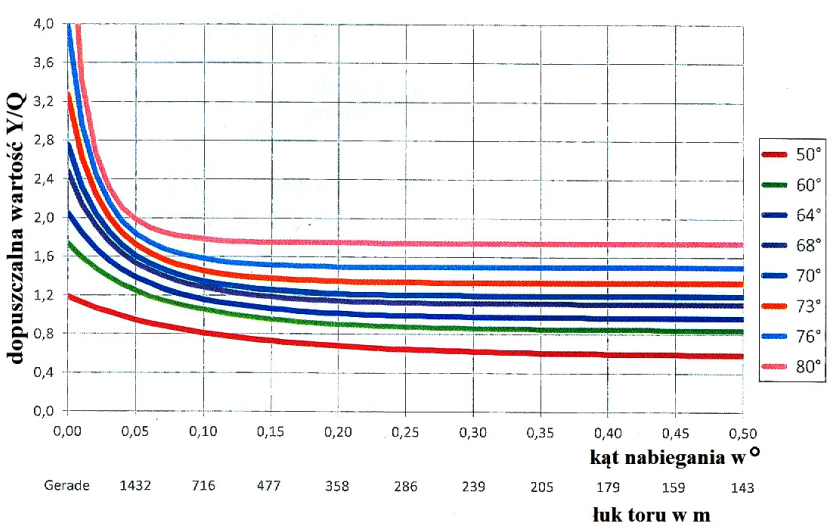

Rys.10. Dopuszczalne wartości wskaźnika (Y/Q) wg rozszerzonego kryterium Nadala w zależności od kąta nabiegania dla różnych kątów pochylenia obrzeża, $2 Q=19$ t i $\mu=0,36$. Promienie luku toru ustalone dla pojazdu o bazie $2 \mathrm{a}-=2,5 \mathrm{~m} \mathrm{wg}$ [2]

Następnie przeprowadzono obliczenia dla wagonu 218 $\mathrm{K}$ (Hbbins) $\mathrm{z}$ rozsuwanymi ścianami o bazie $10 \mathrm{~m}$. Wagon $218 \mathrm{~K}$ przedstawiono na rys. 11.
Wagon 218K (Hbbins) posiada następujące parametry techniczne:

$>$ masa własna wagonu - max.16,5t

$>$ długość ładowana $-14636 \mathrm{~mm}$

$>$ szerokość ładowana-2580 mm

wysokość ładowna-3050 mm

$>$ baza wagonu $-10000 \mathrm{~mm}$

> maksymalny nacisk pionowy zestawu kołowego na tor-22,5t

> maksymalna prędkość wagonu załadowanego $100 \mathrm{~km} / \mathrm{h}$

$>$ maksymalna prędkość wagonu próżnego -120 $\mathrm{km} / \mathrm{h}$

$>$ szerokość (prześwit) toru - $1435 \mathrm{~mm}$.

Wyniki obliczeń wskaźnika wykolejenia (Y/Q) zebrano w tabeli 2.

Przed wykonaniem analizy wyników należy zwrócić uwagę, że wyprowadzona zależność na wskaźnik wykolejenia, określona wzorem (21), przyjmuje postać wzoru (2) jeżeli:

$$
\mu=\mu_{\mathrm{S}}
$$

Wówczas zależność, określona wzorem (18) przyjmuje taką postać pod warunkiem, że

$$
\left(1-\mathrm{e}^{-\mathrm{d} \cdot \mathrm{s}_{\mathrm{y}}}\right)=1
$$

A to oznacza, że funkcja e $\mathrm{e}^{-\mathrm{dsin} \gamma \cdot \sin \alpha} \mathrm{zmierza}$ do wartości 0 .

Wyniki obliczeń dla współczynnika $\mu_{\mathrm{s}}=0,36$ dla wagonu $218 \mathrm{~K}$ przedstawiono w tabeli 3.

\subsection{Radialne ustawianie się zestawu kołowego w łuku, a wskaźnik wykolejenia}

Analizując wyniki przedstawione w tabeli 2 można zauważyć, że wraz ze wzrostem kąta nabiegania $\alpha$, którego wartość rośnie wraz ze zmniejszeniem się promienia łuku toru można wyciagnąć wniosek, że kryterium Nadala może przyjmować:

$>$ większe wartości od tradycyjnie wyliczonych dla małych kątów nabiegania $\alpha$, które pojawiają się na odcinkach prostych toru $\mathrm{R}>1800 \mathrm{~m}$ oraz łukach o dużych promieniach $600 \mathrm{~m}<\mathrm{R} ? 1800 \mathrm{~m}$

$>$ wartości równe tradycyjnie przyjmowanych dla dużych kątów nabiegania $\alpha$, które pojawiają się na łukach małych $250 \leq \mathrm{R}<600 \mathrm{~m}$ oraz na łukach bardzo małych $250 \leq \mathrm{R}<400 \mathrm{~m}$ (definicje zakresów łuków zgodnie PN-EN 14363:2007[12]).

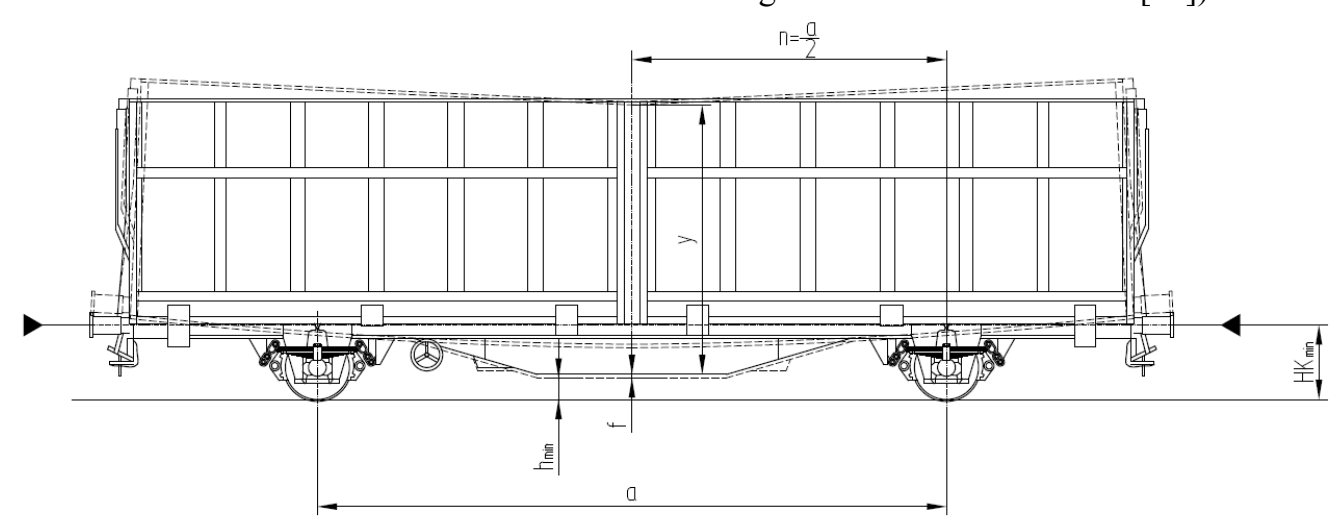

Rys.11. Wagon dwuosiowy typu 218K (Hbbins) z rozsuwanymi ścianami 
Zestawienie wyników obliczeń wskaźnika wykolejenia (Y/Q) dla różnych kątów nabiegania $\alpha$ i współczynnika tarcia $\mu=0,488$ dla wagonu dwuosiowego $\mathrm{z}$ rozsuwanymi ścianami $218 \mathrm{~K}$ (Hbbins)

Tabela 2

\begin{tabular}{|c|c|c|c|c|c|c|c|c|c|}
\hline L.p. & $\begin{array}{l}Q \\
{[t]}\end{array}$ & $\begin{array}{l}\mu_{\mathrm{s}} \\
\text { I-] }\end{array}$ & $\begin{array}{l}d \\
{[t]}\end{array}$ & $\begin{array}{l}\mathbf{R} \\
{[\mathbf{m}]}\end{array}$ & $\begin{array}{l}\alpha \\
\text { [rad] }\end{array}$ & $\begin{array}{l}\alpha \\
{\left[{ }^{\circ}\right]}\end{array}$ & $\begin{array}{l}\sin \alpha \\
{[-]}\end{array}$ & $\frac{Y}{Q}$ & $\frac{Y}{Q}_{N A D}$ \\
\hline 1. & 4,125 & 0,488 & 418,75 & 10000 & $5 \cdot 10^{-4}$ & 0,0286 & $\begin{array}{l}4,9916 \\
10^{-4} \\
\end{array}$ & 1,59 & 0,96 \\
\hline 2. & 4,125 & 0,488 & 418,75 & 5000 & $1 \cdot 10^{-3}$ & 0,0572 & \begin{tabular}{|l}
9,9832 \\
$10^{-4}$
\end{tabular} & 1,26 & 0,96 \\
\hline 3. & 4,125 & 0,488 & 418,75 & 3000 & $1,66 \cdot 10^{-3}$ & 0,0951 & $\begin{array}{l}1,6598 \\
10^{-3}\end{array}$ & 1,08 & 0,96 \\
\hline 4. & 4,125 & 0,488 & 418,75 & 1000 & $5 \cdot 10^{-3}$ & 0,2864 & $\begin{array}{l}4,9986 \\
10^{-3}\end{array}$ & 0,964 & 0,96 \\
\hline 5. & 4,125 & 0,488 & 418,75 & 800 & $6,25 \cdot 10^{-3}$ & 0,3580 & \begin{tabular}{|l|}
6,2482 \\
$10^{-3}$ \\
\end{tabular} & 0,9615 & 0,96 \\
\hline 6. & 4,125 & 0,488 & 418,75 & 600 & $8,33 \cdot 10^{-3}$ & 0,4772 & \begin{tabular}{|l|}
8,3286 \\
$10^{-3}$
\end{tabular} & 0,9610 & 0,96 \\
\hline 7. & 4,125 & 0,488 & 418,75 & 300 & 0,016 & 0,9167 & 0,0159 & 0,96 & 0,96 \\
\hline 8. & 4,125 & 0,488 & 418,75 & 250 & 0,02 & 1,1459 & 0,0199 & 0,96 & 0,96 \\
\hline 9. & 4,125 & 0,488 & 418,75 & 200 & 0,025 & 1,4323 & 0,0249 & 0,96 & 0,96 \\
\hline 10. & 4,125 & 0,488 & 418,75 & 150 & 0,033 & 1,8907 & 0,0331 & 0,96 & 0,96 \\
\hline
\end{tabular}

Zestawienie wyników obliczeń wskaźnika wykolejenia (Y/Q) dla różnych kątów nabiegania $\alpha$ i współczynnika tarcia $\mu=0,36$ dla wagonu dwuosiowego $\mathrm{z}$ rozsuwanymi ścianami $218 \mathrm{~K}$ (Hbbins)

Tabela 3

\begin{tabular}{|c|c|c|c|c|c|c|c|c|c|}
\hline L.p. & $\begin{array}{l}Q \\
{[t]}\end{array}$ & $\begin{array}{l}\mu_{\mathrm{s}} \\
{[-]}\end{array}$ & $\begin{array}{l}d \\
{[t]}\end{array}$ & $\begin{array}{l}\mathbf{R} \\
{[\mathbf{m}]}\end{array}$ & $\begin{array}{l}\alpha \\
{[\text { rad] }}\end{array}$ & $\begin{array}{l}\alpha \\
{\left[{ }^{\circ}\right]}\end{array}$ & $\begin{array}{l}\sin \alpha \\
{[-]}\end{array}$ & $\frac{Y}{Q}$ & ${\frac{Y}{Q_{N A D}}}$ \\
\hline 1. & 4,125 & 0,360 & 418,75 & 10000 & $5 \cdot 10^{-4}$ & 0,0286 & $\begin{array}{l}4,9916 \\
10^{-4}\end{array}$ & 1,808 & 1,200 \\
\hline 2. & 4,125 & 0,360 & 418,75 & 5000 & $1 \cdot 10^{-3}$ & 0,0572 & $\begin{array}{l}9,9832 . \\
10^{-4}\end{array}$ & 1,493 & 1,200 \\
\hline 3. & 4,125 & 0,360 & 418,75 & 3000 & $1,66 \cdot 10^{-3}$ & 0,0951 & $\begin{array}{l}1,6598 \\
10^{-3}\end{array}$ & 1,324 & 1,200 \\
\hline 4. & 4,125 & 0,360 & 418,75 & 1000 & $5 \cdot 10^{-3}$ & 0,2864 & $\begin{array}{l}4,9986 \\
10^{-3} \\
\end{array}$ & 1,202 & 1,200 \\
\hline 5. & 4,125 & 0,360 & 418,75 & 800 & $6,25 \cdot 10^{-3}$ & 0,3580 & $\begin{array}{l}6,2482 \\
10^{-3}\end{array}$ & 1,200 & 1,200 \\
\hline 6. & 4,125 & 0,360 & 418,75 & 600 & $8,33 \cdot 10^{-3}$ & 0,4772 & $\begin{array}{l}8,3286 \\
10^{-3}\end{array}$ & 1,200 & 1,200 \\
\hline 7. & 4,125 & 0,360 & 418,75 & 300 & 0,016 & 0,9167 & 0,0159 & 1,200 & 1,200 \\
\hline 8. & 4,125 & 0,360 & 418,75 & 250 & 0,02 & 1,1459 & 0,0199 & 1,200 & 1,200 \\
\hline 9. & 4,125 & 0,360 & 418,75 & 200 & 0,025 & 1,4323 & 0,0249 & 1,200 & 1,200 \\
\hline 10. & 4,125 & 0,360 & 418,75 & 150 & 0,033 & 1,8907 & 0,0331 & 1,200 & 1,200 \\
\hline
\end{tabular}

Wyniki teoretyczne skłaniają do wyciagnięcia wniosku, że w przypadku ciasnych i średnich zakresów promieni, jednym $\mathrm{z}$ technicznych rozwiązań byłoby zmniejszenie kątów nabiegania poprzez zastosowanie radialnego sterowania zestawów kołowych układów biegowych lub zastosowania sprzęgów wózkowych w lokomotywach. Przykład nowoczesnego wózka z hamulcami tarczowymi oraz radialnym sterowaniem zestawów kołowych typu RC25NT (RadialControl25NewTechnology), zaprojektowany i wyprodukowany przez firmę Eisenbahnlaufwerke $\mathrm{GmbH}$ \&Co.KG w Halle (ELH) jest przedstawiony na rys 12 i rys.13. W wyniku takiego zabiegu, katy nabiegania maleja, zestawy kołowe wpisują się łatwiej w łuk toru. Kolejną korzyścią, jest zmniejszenie zużyć obrzeży kół, co pozwala na zwiększenie żywotności kół jezdnych, a w efekcie na poprawienie konkurencyjności transportu szynowego na rynku przewozowym towarów.

Reasumując mechanizm radialnego sterowania zestawów kołowych wózka RC25NT zapewnia:

$>$ bezpieczną równoległość zestawów kołowych na torach prostych oraz udoskonalone ustawianie się zestawów kołowych w łuku,

$>$ niskie koszty napraw i konserwacji; przy wymianie zestawów kołowych mechanizm sterowania nie musi być demontowany, przez co zapewnione jest utrzymanie dokładności prowadzenia zestawów kołowych. 
Wózek typu RC25NT jest przeznaczony do wagonów towarowych, przystosowanych do nacisku zestawów kołowych na tor, wynoszącego 25t oraz prędkości 100 $\mathrm{km} / \mathrm{h}$.

Badanie pojazdów, a w szczególności wagonów towarowych w stanie próżnym, ma istotne uzasadnienie, gdyż najczęściej dochodzi do wykolejania w tym stanie. Wynika to ze wskaźnika wykolejenia, gdyż wtedy odciążenie koła $\Delta \mathrm{Q}$ może być decydujące dla bazowej wartości nacisku Q. Wyliczone wartości kątów nabiegania dla analizowanych przypadków są realne i pokrywają się z praktyką eksploatacyjną,

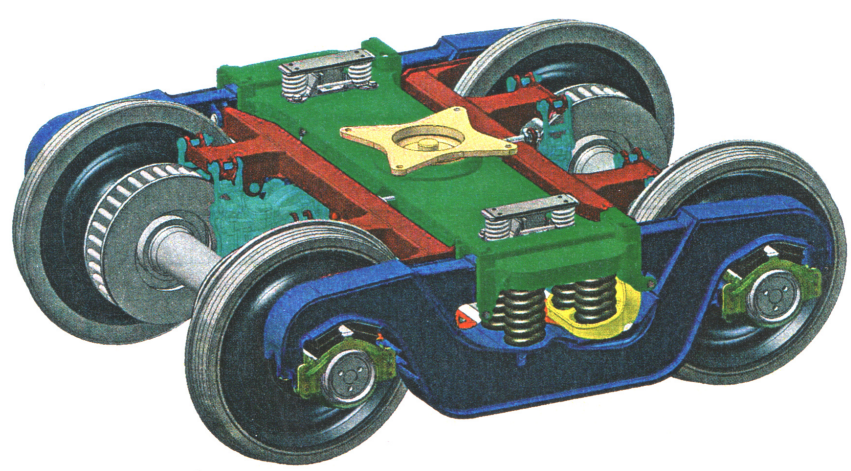

Rys.12.Wózek RC25NT, przeznaczony do ciężkich przewozów towarowych wg [5]

Należy podkreślić, że każdy luz wzdłużny zwiększa możliwość wpisywania się pojazdu w łuki. W ten sposób zmniejsza się kąt nabiegania w łukach. Uzasadnia to wzór na określenie minimalnego promienia tuku toru, przez który może przejechać pojazd np. dwuosiowy wagon towarowy. W przypadku przejazdu przez łuk o promieniu $\mathrm{R}$ wagonu dwuosiowego o bazie 2 p, luzach poprzecznych $2 \mathrm{q}$, luzach wzdłużnych $2 \mathrm{q}_{\mathrm{w}}$ i luzie zestawu kołowego $\mathrm{w}$ torze $\varepsilon$ minimalny promień łuku toru, w który może wjechać pojazd wynosi:

$$
\mathrm{R}=\frac{\frac{\mathrm{p}}{2}-\left[\frac{\sin \operatorname{arc} \cos \psi}{\operatorname{tg} \gamma}+\frac{\mathrm{q}_{\mathrm{w}}}{\mathrm{s}}\right] \frac{\varepsilon}{2}}{\left(\frac{\sin \operatorname{arc} \cos \psi}{\operatorname{tg} \gamma}+\frac{\mathrm{q}_{\mathrm{w}}}{\mathrm{s}}-\frac{\varepsilon+2 \mathrm{q}}{\mathrm{p}}\right)}
$$

Wyniki uzyskanych kątów nabiegania $\alpha$ dla wagonu $\mathrm{z}$ rozsuwanymi ścianami typu $218 \mathrm{~K}$ są realne i mają swoje potwierdzenie w praktyce kolejowej.

Należy wziąć pod uwagę, że wskaźnik wykolejenia, jako kryterium w tradycyjnej formie jest funkcją dwóch zmiennych tzn. kąta pochylenia obrzeża $\gamma$ oraz współczynnika tarcia $\mu$ pomiędzy kołem a szyną. Dzięki dalszym badaniom udało się uwzględnić w kryterium wykolejania kąt nabiegania $\alpha$. Należy podkreślić, że wskaźnik wykolejania jest zależny od współczynnika tarcia między kołem a szyna, który z kolei zależy od:

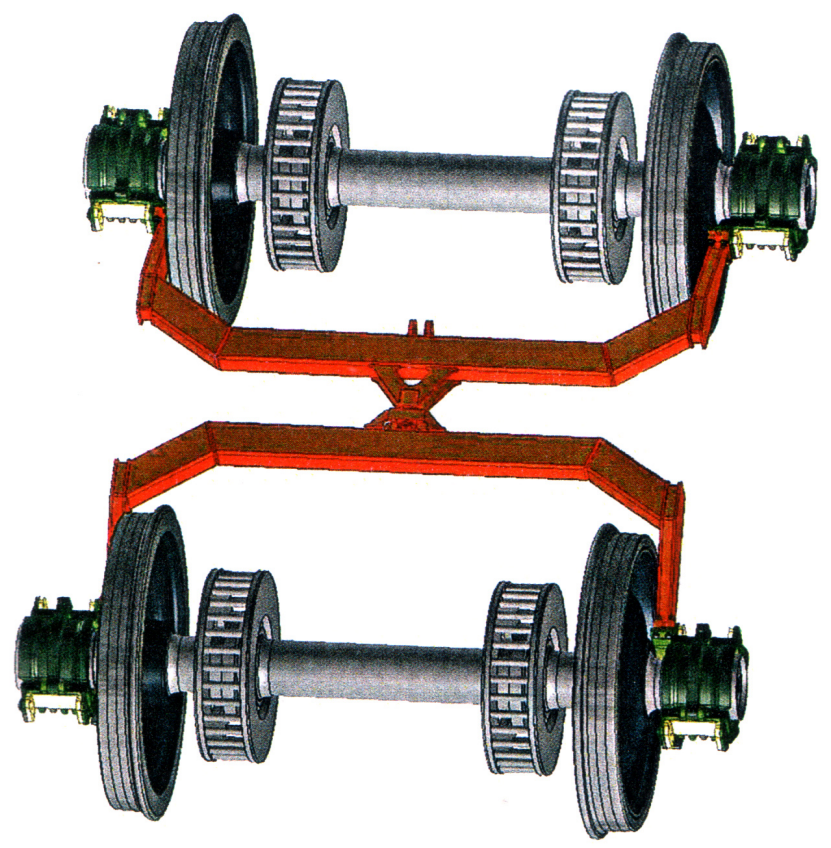

Rys.13. Mechanizm sterowania radialnego wózka RC25NT wg [5]

$>$ prędkości pojazdu,

$>$ warunków atmosferycznych (temperatura otoczenia, wilgotność powietrza),

$>$ wyposażenia pojazdu w urządzenia do smarowania obrzeży kół,

$>$ wyposażenia $\mathrm{w}$ urządzenia stacjonarne przytorowe do zwilżenia powierzchni szyn na łukach toru (stosowane głownie przez koleje szwajcarskie SBB oraz koleje austriackie ÖBB),

$>$ wyposażenia pojazdu $\mathrm{w}$ urządzenia do piaskowania,

$>$ zanieczyszczenia i zużycia szyn (patrz rys.2),

$>$ chropowatości powierzchni tocznej i obrzeży kół oraz szyn kolejowych itd.

Zależność wskaźnika wykolejenia dla poszczególnych kątów pochylenia obrzeża $\gamma$ od współczynnika tarcia przedstawiono w tabeli 4.

Należy zwrócić uwagę na to, że wartość współczynnika tarcia $\mu=0,36$ nie jest wartością maksymalną występującą w kolejnictwie. Norma PN-EN 14363:2007 [12] przedstawia wykres zależności wskaźnika wykolejania od kąta pochylenia obrzeża dla różnych współczynników tarcia. Wykres ten jest przedstawiony na rys.14.

Jak widać z rys.14, współczynnik tarcia między kołem i szyną może wynosić nawet $\mu=0,5$. Jak wynika $z$ doświadczeń eksploatacyjnych, zdobytych poza granicami kraju współczynnik tarcia może osiagnąć nawet w sprzyjających warunkach wartość $0,6[1,3,4]$. Tak więc kryterium Nadala, jako wskaźnik wykolejania o wartości 1,2 ma charakter umowny i jego spełnienie w warunkach ekstremalnych może być niewystarczające. 
Zależność współczynnika wykolejenia (Y/Q dla różnych kątów pochylenia obrzeży koła od współczynnika tarcia między kołem a szyną

Tabela 4

\begin{tabular}{|l|l|l|l|l|l|l|l|}
\hline I.p. & $\begin{array}{l}\text { Wartość kąta } \\
\text { pochylenia } \\
\text { obrzeża } \boldsymbol{\gamma} \\
\text { [?] }\end{array}$ & $\begin{array}{l}\text { Wspólczy-- } \\
\text { nnik } \\
\text { tarcia } \\
{[-]}\end{array}$ & $\begin{array}{l}\text { Wartość } \\
\text { wskaźnika } \\
\text { wykolejenia }\end{array}$ & $\begin{array}{l}\text { Wpólczynnik } \\
\text { tarcia } \\
\text { [-] }\end{array}$ & $\begin{array}{l}\text { Wartość } \\
\text { wskaźnika } \\
\text { wykolejenia } \\
\text { [-] }\end{array}$ & $\begin{array}{l}\text { Wspólczynnik } \\
\text { tarcia } \\
\text { [-] }\end{array}$ & $\begin{array}{l}\text { Wartość } \\
\text { wskaźnika } \\
\text { wykolejenia } \\
\text { [-] }\end{array}$ \\
\hline $\mathbf{1}$ & $60^{\circ}$ & 0,36 & 0,845 & 0,2 & 1,137 & 0,1 & 1,391 \\
\hline $\mathbf{2}$ & $61^{\circ}$ & 0,36 & 0,875 & 0,2 & 1,178 & 0,1 & 1,443 \\
\hline $\mathbf{3}$ & $62^{\circ}$ & 0,36 & 0,906 & 0,2 & 1,221 & 0,1 & 1,498 \\
\hline $\mathbf{4}$ & $63^{\circ}$ & 0,36 & 0,939 & 0,2 & 1,265 & 0,1 & 1,557 \\
\hline $\mathbf{5}$ & $64^{\circ}$ & 0,36 & 0,972 & 0,2 & 1,312 & 0,1 & 1,618 \\
\hline $\mathbf{6}$ & $65^{\circ}$ & 0,36 & 1,007 & 0,2 & 1,360 & 0,1 & 1,683 \\
\hline $\mathbf{7}$ & $66^{\circ}$ & 0,36 & 1,042 & 0,2 & 1,411 & 0,1 & 1,752 \\
\hline $\mathbf{8}$ & $67^{\circ}$ & 0,36 & 1,079 & 0,2 & 1,465 & 0,1 & 1,825 \\
\hline $\mathbf{9}$ & $68^{\circ}$ & 0,36 & 1.118 & 0,2 & 1,521 & 0,1 & 1,903 \\
\hline $\mathbf{1 0}$ & $69^{\circ}$ & 0,36 & 1,158 & 0,2 & 1,581 & 0,1 & 1,987 \\
\hline $\mathbf{1 1}$ & $70^{\circ}$ & 0,36 & 1,200 & 0,2 & 1,644 & 0,1 & 2,076 \\
\hline $\mathbf{1 2}$ & $71^{\circ}$ & 0,36 & 1,243 & 0,2 & 1,710 & 0,1 & 2,173 \\
\hline $\mathbf{1 3}$ & $72^{\circ}$ & 0,36 & 1,289 & 0,2 & 1,781 & 0,1 & 2,276 \\
\hline $\mathbf{1 4}$ & $73^{\circ}$ & 0,36 & 1,336 & 0,2 & 1,856 & 0,1 & 2,389 \\
\hline $\mathbf{1 5}$ & $74^{\circ}$ & 0,36 & 1,386 & 0,2 & 1,936 & 0,1 & 2,511 \\
\hline $\mathbf{1 6}$ & $75^{\circ}$ & 0,36 & 1,438 & 0,2 & 2,022 & 0,1 & 2,644 \\
\hline $\mathbf{1 7}$ & $76^{\circ}$ & 0,36 & 1,493 & 0,2 & 2,114 & 0,1 & 2,791 \\
\hline $\mathbf{1 8}$ & $77^{\circ}$ & 0,36 & 1,551 & 0,2 & 2,213 & 0,1 & 2,952 \\
\hline $\mathbf{1 9}$ & $78^{\circ}$ & 0,36 & 1,612 & 0,2 & 2,320 & 0,1 & 3,131 \\
\hline $\mathbf{2 0}$ & $79^{\circ}$ & 0,36 & 1,677 & 0,2 & 2,437 & 0,1 & 3,330 \\
\hline $\mathbf{2 1}$ & $80^{\circ}$ & 0,36 & 1,746 & 0,2 & 2,563 & 0,1 & 3,555 \\
\hline
\end{tabular}

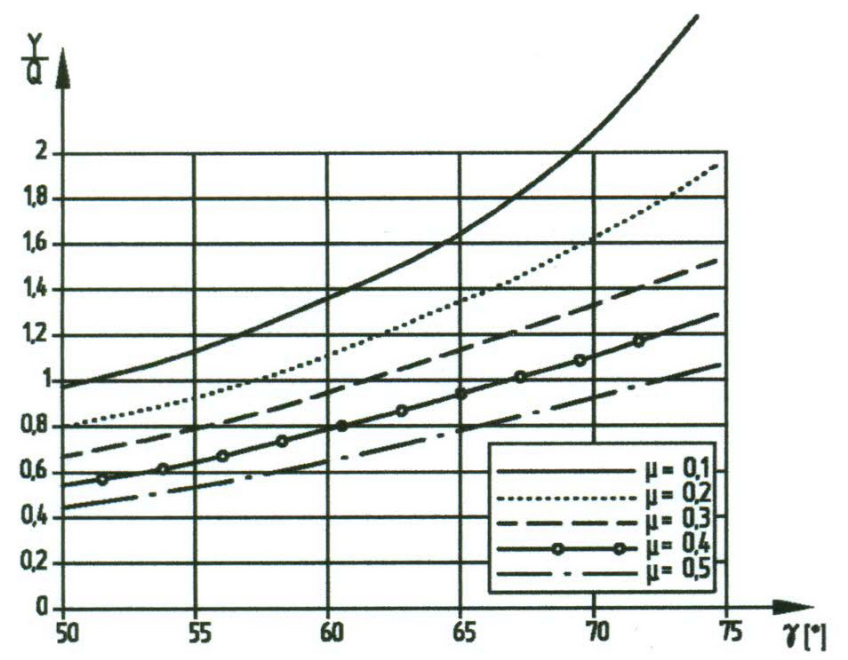

Rys.14.Przebieg funkcji wskaźnika wykolejenia (Y/Q) w zależności od współczynnika tarcia $\mu$ między kołem a szyną oraz kąta pochylenia obrzeża $\gamma$ koła wg PN-EN 14363:2007 [12]

\section{WNIOSKI}

Jak widać z przedstawionych analiz kryterium wykolejenia, zwane kryterium Nadala mające już bardzo długą historię podlega ciagłemu rozwojowi. Rozwój ten odbywa się na drodze analiz teoretycznych oraz badań empirycznych. Badanie samego kryterium i jego uściślanie ma na celu, zwiększenie bezpieczeństwa kursujących pojazdów podczas przejazdu w ekstremalnych warunkach (mała prędkość, wysoki współczynnik tarcia) przez tory wichrowate. Zwiększenie tego kryterium ,w sensie wartości, daje bardzo duże korzyści i przyczynia się do zwiększenia konkurencyjności transportu szynowego. Warto zauważyć, że w okresie eksploatacji pojazdu szynowego, dopuszczalna wartość współczynnika wykolejenia zmienia się w zależności od prędkości pojazdu (współczynnika tarcia), trajektorii toru (tory proste, łuku o dużym promieniu, łuki o małym promieniu oraz łuki o bardzo małym promieniu), wartości kąta pochylenia obrzeża, stanu utrzymania zarysu zewnętrznego koła oraz szyn. Badania nad wskaźnikiem wykolejenia (Y/Q) powinny być przeprowadzone równolegle $\mathrm{z}$ pracami nad zabezpieczeniami technicznymi pojazdów szynowych przed wykolejeniami..Polega to na ciagłych inwestycjach technicznych w zakresie wyposażeniu taboru szynowego w system zapobiegawczo-prewencyjny, jeśli chodzi o wykolejenia. W przypadku zastosowania mechanizmów, umożliwiających qausi-radialne lub radialne ustawianie się zestawów kołowych w łuku, osiąga się jeszcze jedną zaletę zawieszenia lub układu biegowego, do jakich można zaliczyć mniejsze zużycie obrzeża kół zestawu kołowego oraz powierzchni szyn. Zgodnie z tendencjami rozwoju pojazdów szynowych, rośnie zapotrzebowanie na ultralekkie konstrukcje. W związku z powyższym, bezpieczeństwo przed wykolejeniem nabiera priorytetowego znaczenia. 


\section{LITERATURA}

[1] Böhmer A., Ertz M., Kontothe k., Bucher-Mersch F., Klimpel T.: Beanspruchungen von Schienen unter $d y$ namischen und thermischen Belastungen. ZEV Rail Glasers Annalen. Nr. 3 i 4.2003.

[2] Dede J., Reimann U : Nadals Gleichung, erweitert um den Analaufwinkel. ZEVrail nr. 42014

[3] Kik.W., Menssen R., Moelle D.: Kräfte und Verschleiss in der Wendenschleife und im Abzweig einer Weiche. Der Eisenbahningenieur 04.2003.

[4] Krugmann H.L.: Lauf der Schienefahrzeuge im Gleis. Eine Einführung. Oldenburg. Verlag MünchenWien.1982

[5] Scholdan D., Gabriel N, Kik W.: Ein neues gleisfreundliches Drehgestell für den schweren Güterverkehr. Glassers Annalen. Sonderheft Tagungsband. Moderne Schienefahrzeuge. 09.2011.

[6] Sobaś M.: Zawieszenia i układy biegowe wagonów towarowych. Wydawnictwo IPS Tabor 2014.
[7] Sobaś M.: Analiza przejazdu wagonów towarowych dwuosiowych przez tuk o minimalnym promieniu (1). Pojazdy Szynowe nr 1/2003

[8] Sobaś M.: Stan i doskonalenie kryteriów bezpieczeństwa przed wykolejeniem pojazdów szynowych (1). Pojazdy Szynowe $n r$ 4/2005.

[9] Sobaś M.: Stan i doskonalenie kryteriów bezpieczeństwa przed wykolejeniem pojazdów szynowych (2). Pojazdy Szynowe $n r$ 2/2006.

[10] Karta UIC 510-2: Pojazdy doczepne. Warunki dla stosowania kót o różnych średnicach $w$ układach biegowych różnego typu. 4-te wydanie z października 2002 i kwietnia 2004.

[11] PN-EN 13715+A1:2011: Kolejnictwo. Zestawy kołowe $i$ wózki. Koła. Zewnętrzne zarysy wieńców kót.

[12] PN-EN 14363:2007:Kolejnictwo-Badania właściwości dynamicznych przed dopuszczeniem pojazdów szynowych. Badania właściwości biegowych $i$ próby stacjonarne.

[13]Raport ORE/ERRI B55 Rp.8: Sicherheit gegen Entgleisen von Güterwagen in Gleisverwindungen. Bericht 8 (Schlussbericht). Utrecht. April, 1983. 